\section{BIRDS OF THE BESNARD LAKE AREA, NORTH-CENTRAL SASKATCHEWAN, 1968-1994}

JON M. GERRARD, GARY R. BORTOLOTTI, KAREN L. WIEBE. Special Publication No. 20, SNHS. No. 2, Manley Callin Series. 97pp. 1996.

The tenth SNHS regional bird publication is a welcome addition to the Society's tradition of detailed accounts of the birds of various parts of the province. The authors - all trained scientific researchers - have not allowed the rigorous bounds of the scientific method to restrict their evident enthusiasm as naturalists. Their anecdotes and comments illuminate and invigorate their descriptions of the birds of a formerly littleknown part of the province.

The book has an interesting history, arising out of a long-term study of Bald Eagles initiated by John Gerrard and Doug Whitfield in 1967. That study has had many participants, including Gary Bortolotti whose Ph.D. studies contributed much to it, and its results have been widely published (notably in Gerrard and Bortolotti's book The Bald Eagle: Haunts and Habits of a Wilderness Monarch, published by the Smithsonian Institution in 1988). Fortunately for Saskatchewan, Gary Bortolotti remained in the province, and began his own long-term study (of American Kestrels) in the Besnard Lake area. The third author, Karen Wiebe, studied Kestrels with Gary for her Ph.D. and has contributed much to the science of the book apart from her delightful line drawings; there are only eight of these and more would have been welcome. Clearly the authors and their collaborators (among whom they give particular credit to Doug Whitfield) have kept careful notes far beyond those required for their research, perhaps with this book in mind but perhaps just because they are keen and observant naturalists. These notes have allowed them to assemble a comprehensive account of over 200 species of this fascinating part of the southern belt of the western boreal forest.

The book begins with a characteristically sweeping and quantitative Foreword by Stuart Houston (who tells us, among other things, exactly how many papers each author has published). Brief biographies of the authors are followed by a description of the study area and its history, geology, soils, vegetation, and climate. Throughout, photographs of habitats and localities illustrate the rich ecological diversity of this area, which may surprise many whose image of the province is of flat wheatfields and rolling grasslands. The authors draw attention to the recent increase in logging in the area, to the much more comprehensive removal of tree cover by current forestry practices compared with former ones, and to the critical role of fire in the forest's ecology, exemplified by the enormous fire which burned for six weeks in 1995 and consumed part of the study area. One can only hope that the authors, if not others, will be able to continue bird counts and observations to document the effects of these changes on the avifauna.

The status of many - perhaps most - of the entries in the Species Accounts is derived from observations made incidentally in the course of research and travel. As one would 
expect, the relative amounts of information on different groups of birds reflect the research projects of the authors. Bald Eagles are best studied from the water, and waterbirds are thoroughly documented. Only the raptors encountered during the kestrel studies are described in comparable detail. Shorebirds and, particularly, small songbirds, are mostly listed with only a line or two of information. This is particularly disappointing because there are some fascinating nuggets here that deserve further study: Bay-breasted Warblers, for example, have not been recorded in the last 17 years, and there is only one record of Golden-crowned Kinglet. The authors did carry out owl censuses and forestbird transects in a commendable effort to lessen their dependence on observations made during their focused research projects, but one is left wondering whether some of the anomalies in the passerine records might still reflect the inevitable biases of the field work.

That said, the information on water birds and raptors is comprehensive and fascinating. Clearly the region is of exceptional interest in the contrast of aquatic habitat types between the two halves of Besnard Lake, and in the abundance of piscivorous species. The benefit to kestrels of the opening up of the forest by logging roads is well documented, as is the surprising abundance of Boreal Owls that Bortolotti discovered during his research. It is refreshing to read of a bird fauna dominated by long-term increases in abundance, or stable populations, rather than peppered with references to population declines! However there is a warning in the discussion of the increases in fish-eating birds, likely due to overfishing of the larger predatory fish, allowing increases in abundance of the smaller "forage" fish on which many of these birds feed. As fishermen become more aware of declines in their primary target species, they will likely blame the birds for it, as has happened so widely elsewhere on this continent. Naturalists will need to be on their guard for the inevitable demands for "control" of fish-eating birds by fishermen unwilling to accept responsibility for their own intemperate behaviour.

This is a fascinating book which succeeds admirably in presenting solid information in a palatable and interesting style. The authors are particularly to be congratulated for retaining and communicating their underlying enthusiasm for natural history, which remains the essential foundation to the rigorous science for which the authors are already well known.

- Reviewed by Tony Diamond, Director, Atlantic Cooperative Wildlife Ecology Research Network, UNB, Fredericton, NB

\section{BRITISH COLUMBIA - A NATURAL HISTORY}

RICHARD CANNINGS and SYDNEY CANNINGS. 1996. Greystone Books, Douglas \& McIntyre, Vancouver. 320 pages, 7 1/2" $x$ $10 "$ ", $\$ 45.00$ cloth.

If Christmas money is burning a hole in your pocket, or if you have been wondering what to get your sister Mary for her birthday, here is the perfect answer. The book is about the natural history of B.C. but, as I leafed through this handsome volume, among the first of the many gorgeous colour pictures to catch my eye were two of familiar prairie species. The first is a larger-than-fullpage shot of a Yellow-headed Blackbird perched among exploding cattail seed heads; the other is a stunning 